\title{
Quality Administration and Management in Higher Education in Nigeria: Implications for Human Resource Development
}

\author{
Gbenga M. Akinyemi ${ }^{1} \&$ Norhasni Zainal Abiddin ${ }^{1}$ \\ ${ }^{1}$ Department of Professional Development and Continuing Education, Faculty of Educational Studies, Universiti \\ Putra Malaysia, Malaysia \\ Correspondence: Norhasni Zainal Abiddin, Department of Professional Development and Continuing Education, \\ Faculty of Educational Studies, Universiti Putra Malaysia, Malaysia. E-mail: nonie@putra.upm.edu.my
}

Received: March 3, 2013

Accepted: March 26, 2013

Online Published: March 26, 2013

doi:10.5539/ies.v6n4p225

URL: http://dx.doi.org/10.5539/ies.v6n4p225

\begin{abstract}
The dynamic changes in today's world have made countries of the world masters of their own destinies. In this light, it has become noted today that 'the affluence or penury of nations depends largely on the quality of higher education'. This is informed by the fact that higher education systems of a nation is the 'machinery of manpower creation' of the nation and as a result nations have to embrace quality on a continuous basis to be able to be in touch with the realities of today's change in technological, sociological and economical dimensions. Quality higher education system will produce quality skills and quality human capacity. Therefore, in adjustment to needs for development countries such as Nigeria should embrace and implement Continuous Quality Improvement (CQI), Total Quality Management (TQM) in the universities and Higher Education administration for the purpose of all-round Human Resource Development. TQM and CQI implementation in the university system will go a long way in expanding the skills and capacity of the academic staffs and consequently that of the students. In effect, there will be increase in Human Capital Development across the nation and the attendant economic growth, technological growth, innovation and general Human Resource Development towards National Development. Thus, this article reviewed the literatures on quality administration and management in higher education in Nigeria with the aims of highlighting the implication of human resource development.
\end{abstract}

Keywords: human resource development, continuous quality improvement, higher education, technology, economic growth, total quality management

\section{Introduction}

Education has been noted and identified to be a national consumption, in that it dictates the bearings and positions of a nation in development and overall growth (Alam, Hoque, Khalifa, Siraj, \& Ghani, 2009). Education is at the threshold of a country's development, in that it influences and moderates the level and dimensions of development in a nation. In essence, the management of education of a country directly influences the economic and developmental life of the country, as a result of this greater attention are being paid to th management of education in developed countries (Kaul, 2010). Educational management has to with the practice and operation of education organizations (Lange, 1988). In line with this, the management of education of a country plays an important role in the overall outcome and development of the nation. From the forgoing efficient management of education system is very vital and has an important bearing on the quality of labor and manpower of the country; and in the long run the national economic growth (Cho \& McLean, 2004; G. N. McLean, 2006; Peters, 2009). This is based on the fact that, the skills, labors and human resource deposit of any country are trained and developed through education management, especially higher education management; and the management of education in turn depends on the quality human resource at its disposal (Ekundayo \& Ajayi, 2009).

Therefore, higher education management and Human Resource Development are seriously interdependent; higher education produces human resource for national manpower need and at the same time human resource are inputs for higher education (Folger, Astin, \& Bayer, 1970; Nakpodia, 2011; Pathik, Chowdhury, \& Habib, 2012). In this light, higher education in a country is a machinery for development and the human resource input of it must be taken into due consideration, in the management of it, as well as in national character of a country as a whole. Based on the two sideways benefits of Human Resource Development to higher education in a country, 
the management and administration of higher education must be positioned and effective towards proper input and output of human resource for national growth (Dauda, 2010; Suri, Boozer, Ranis, \& Stewart, 2011).

Human resource inputs in higher education are the manpower requirement, the manpower need by higher education to function properly in its day to day business, in terms of lecturing staffs, support staffs, service staffs and consultants (Ekundayo \& Ajayi, 2009; Samoff \& Carrol, 2003). While the human resource output of higher education are the skilled labor, technocrats, professionals and experts who serve as the labor strength for the country; consequently the quality of this labor strength, the human resource output of higher education, depends wholly on the quality and efficiency of the human resource input in higher education (Ekundayo \& Ajayi, 2009). The importance of quality, that is the need for quality, and the level of quality of labor places additional importance on the human resource aspect of higher education; the input factor of higher education, in effect this calls for adequate management and administration of higher education towards achieving quality in human resource output for the country. From the forgoing, management and administration of higher education is vital in Human Resource Development (HRD), as a result of the fact that human resource input in higher education system requires management and administration for the purpose of quality yield in output.

\section{Method}

This study explores the importance of Human Resource Development in higher education systems, that is, the university and other institution of higher learning in Nigeria. The study employs the use of explorative style of making use of relevant studies, empirical and conceptual, in the background of HRD in higher education in developed countries as well as in Nigeria; in order to get to a useful conclusion.

\section{Management and Administration as Important Factors for HRD in Higher Education}

Theories of management have proved to be of viable use and application in organizations settings and operations, such as academic organizations like a university. The word management generally implies the art and process of getting things done by others towards the achievement of preset goals and objectives (Keller, Parameswaran, \& Jacob, 2011; Richard, 2011). Management involves the implementation of business objectives with a strategic aim of reaping in the gains of business, therefore on this note, the word 'management' as it is applicable in university and higher education management is 'business in nature'. That is when the term management is used and applied in a setting like university and institutions of higher learning; there must be expectation of 'profit and gains' as a result of the fact that management happens in business for the sole aim of profit advancement and survival (Wheelen \& Hunger, 2011).

In the light of this, when management is conceptualized, in higher education setting, as a tool for output and performance effectiveness; then there is a reference 'profits' accruable from such management expeditions, that is profits in terms of 'high turnout of high level manpower', ' high return rates to the general economy in terms of technology and production' (Gupta, 2010). Every business operate mainly for survival and profitability, therefore a university as a center of business of human development has to be well managed for the purpose of achieving its goals of survival and profitability in terms of creation and development of relevant skills for the society. In the light of this, universities as well as other institutions of higher learning are basically for the business of molding people into useful capacities and skills for development at individual level, organizational level and national level (Dauda, 2010; Smart \& Paulsen, 2011). In theory, practice and principle a university or an institution of higher learning are not meant to operate for business profit or gain, as a result of the fact that institutions of higher learning are 'not for profit' organizations (Hansmann, 1987; Wynne, 2010). At the same time, management efforts of higher education systems such as universities at human development level, is primarily aimed at increasing gains and profits in terms of manpower development; avoid wastage in terms of drop out. Management in this light, is not about material management to increase monetary gains and profits, but the management of available resources towards sustainable human capital and human capacity development for the socio-economic benefit of the country (Ekundayo \& Ajayi, 2009).

Principally, being 'a non for profit' organization, universities and higher education institutions preferably favor the use the of the word 'administration' to describe quality assurance processes involved in meeting the desired goals. That is the desired goals of high manpower turn out rate and low dropout rate. In this sense, in higher education parlance, the word management and administration is almost similar in technicality and usage, but the culture of universities and citadels of higher learning prefer the use of the word administration being nonfor-profit organizations (Adamolekun, 1983; Frederickson, Smith, \& Larimer, 2011).

Administration involves formulation of policies and directing activities towards achievement of reset goals and objectives. However, from whichever way one look at the process of controlling process towards efficiency in the university, either from the way of administration or from the way of management, administration should be 
used to ensure quality for the purpose of adequate and efficient manpower output, in terms of human resource development for the county. It has been established that success in the quality of human capital development of a system of higher learning depends on administration and input of human resource for its operation (Adamolekun, 1983; Agarwal, 2009; Dauda, 2010). Therefore, from the forgoing administration as a tool for managing institutions of higher learning should be effectively used in the input of human resource in its operations.

\section{Deming's Chain Reaction Model: An Imperative for Continuous Quality Improvement in Universities' Human Resource}

Chain Reaction Model is one of the principle philosophies of Deming, William Edward Deming (Evans, Thornton, \& Usinger, 2012). Deming a renowned father of quality whose models and philosophies on quality have enjoyed world wide application and even to the development and advancement of countries such as Japan and other countries; the same philosophies are applicable in higher education setting (Evans et al., 2012). Japan has demonstrated the importance and effectiveness of Deming's philosophies especially in the production and manufacturing economy of the country; on this note Toyota Plants have successfully implemented the experimentation of Deming's philosophies over the years (Hallam, Muesel, \& Flannery, 2010). Toyota Production Systems has over the years feared well in terms of Six Sigma and CQI, Continuous Quality Improvement, and it has widely been described that the genesis of CQI and Six Sigma emanated from Toyota Production System. Deming's philosophies always get the institutions or organizations applying it thinking and working in unity for the purpose of the improving how things are done and the overall output of process. The effects of Deming's quality philosophies are very prominent on the employees and as result employees are developed in terms of knowledge stocks acquisition.

Therefore, Deming's CQI and allied philosophies usually have total effect on the institution or organizations in which the philosophies are being applied in the sense that the total elements of organizations in question are affected by the quality approaches, that is, the process, the products and the employees are all affected positively (Black, 2010; Hallam et al., 2010). In this vain, it is on record that CQI have been tested and validated in several manufacturing organizations and that have also been applied to the tune of successful outcome in universities and institutions of higher learning across the globe. Higher education at any country of the world is very crucial to the overall economic performance of the people, in terms of the input of the developed people to the economy of the nation (Evans et al., 2012).

Education is dynamic and changes in nature, education changes with the movement and changes of the world and as a result of this proper change management approaches have to be applied by management and administration for university and higher education system in Nigeria, at institutional level and national level (Lorenzi \& Riley, 2000; Shortell et al., 1995). Change is a double-edged sword in production and process operation, considering the fact universities are institutions of higher learning where learning and knowledge are processed, through cutting edge researches and innovation, to the products of human capital development.

In this light, change can be to the advantages of educational institutions of higher learning, if properly managed on other way round, change can be inimical to the progress of knowledge growth and advancement if not properly managed (Biggs \& Tang, 2011). For instance, the whole of today's world is moving towards smart technology, in the face of smart phones, Personal Digital Assistants (PDAs) or otherwise called palm computers. These are current technology change of the world that have equally changed or modified the ways of life, culture and attitude of world including the global economy (Cozzens, 2012; Fulton-Calkins \& Stulz, 2008). Almost every aspect of world activities are getting affected by the drive of smart technology of today's world while the developing youth group of human population are the most hit group, of the influence of smart driven world (Castells, 2010; Ito, 2005; Kreutzer, 2009a). In this light, the present generation has been referred to as 'generation mobile' as a result of their vast use of mobile technology.

These mobile assistants can be of very vital application in teaching and learning and can be adequately directed towards productive learning. Mobile smart appliances, like smart phones and Personal Digital Assistants enhances and improves users social capital (Kreutzer, 2009). social capital refers to productive benefits such as information and knowledge accruable from social networks and connections of several people (Laplante, 2011). That is when people of different intelligent disposition, ideas connect together via a physical connecting link like social gathering such as social club or peer groups; or via technology-enabled forum such that can be provided by smart phones there is bound to be 'diffusion, percolation and distribution' of knowledge information from the 'highly-knowing' to the 'lowly-knowing' (Kreutzer, 2009; Laplante, 2011). It should be noted, that Social Capital Theory as a knowledge capacity gains as a result of belonging to social networks or social circles is an integral component of Human Capital Development Theory (HCDT) which emphasizes the economic gains 
accruable from additions of knowledge and information (Bhagavatula, Elfring, Van Tilburg, \& Van De Bunt, 2010; Ellison, Steinfield, \& Lampe, 2011; Woolcock \& Narayan, 2000).

Considering the virility of smart technology as in smart phones with which students can assess knowledge information 'on the go', university administrations in Nigeria should see this as imperative wind of change in higher learning and in line with this, positive change management should be put in place. This is because if this change is not properly managed, it can manage the students towards academic drop out and social distractions occasioned by smart technology (Valenzuela, Park, \& Kee, 2009). In line with this, educational use of Information Communication Technology (ICT) and Smart Appliances (BlackBerry phones, Windows Phones, IPhones, Androids) can be synchronized into teaching and training activities of the university by the administrations, as Continuous Quality Improvement (CQI) and Total Quality Management (TQM) approach for knowledge growth towards Human Resource Development in the universities and colleges of higher learning among students as well as the teachers (Kumar, 2011). CQI and TQM are philosophies based on exact accuracy that is zero defect, 99.9999999999 percent defect free. In the same vain, framework of university studentship can be designed to encourage students to use the large chunk of their free or social time on further study via university administered applications and social networks (Kumar, 2011). The effect of this is that there will be shortage in time used by students, and scholars as well, on 'socials- without learning' and increased overall time for learning for scholars, the lecturers and students (Garaj, 2010). By visiting social network places via ICT students and scholars learn incidentally; and these learning will accumulate to increase the knowledge stocks and human capital and in effect develop human resource. Quality management and administration in the aspect of ICT and Smart technology is viable in human capital development of the university communities in Nigeria that is mainly the lecturers and students. In line with this supporting environments and infrastructures for e-learning enabled by ICT and Smart Technology should be enhanced in order to curry in the maximum benefits of today's technology (Valenzuela et al., 2009).

The use of ICT and the latest smart technology for educational purpose has been made popular and acceptable in developed countries and some other developing countries, US, UK and even in India. In line with this, Valenzuela et al., (2009) in their studies in the US on learning and social networks, found more advantages of social networks to learning achievement among college students. In a similar study in South Africa, Kreutzer (2009) highlighted vital importance of Smart Phones in learning and development. Still on this, also Kumar (2011) discusses the impact of smart phones and the latest technology on education on the positive side. From the forgoing, quality assurance and implementation in the University system in Nigeria should be directed towards the intervention of the latest technology and deploying such technologies towards facilitating overall development and efficacy. In line with this, the administrative framework of the university systems at the central level, the NUC, and institutional level should embrace support to the latest e-learning technology (Kumar, 2011). The overall effect of proper quality administration and management of university systems, based on the Deming's Chain Reaction Model will bring about an all-around turn around in Human Resource Situation in Nigeria (Ito, 2005; Onovughakpo, 2012; Potnis, 2010).

Deming's Chain Reaction Model is based on the principle that proper and continuous quality improvement approach brings about vital returns to the management also. That is quality improvement does not only positively affect the targeted customer or process, but instead it also helps the organization itself (Morrison, 2010; Okechukwu \& Okechukwu, 2011; Schwantz, 2012). In Chain Reaction Theory, improvement results in lower cost and better productivity, on this note the reaction or outcome of embracing quality improvement is lower cost and increased productivity and in the long run it causes long term competitive strength (Sousa \& Voss, 2012). This overall effect or reciprocator effect of quality improvement to the organization embracing quality is what Deming called chain reaction. It is known as Chain Reaction based on the sense that improvement in one component of the process or products affect the other components of the process and products positively (Sousa $\&$ Voss, 2012).

Therefore, in the parlance of Higher education in Nigeria, Total Quality Management (TQM) as it has been implemented in other developed and developing countries (Quinn, Lemay, Larsen, \& Johnson, 2009), Such as South Africa, India, US and so on, is the answer to the yearnings for sustainable development in higher education system and Nigerian national life as a whole; the gains of implementing such quality approach will affect and improve all aspect of higher education process and products in Nigeria in terms Human Resource Development. Quality assurance procedures implemented to improve Human Resource Development among the academic staff will equally expand the skills and intellectual ability of the university students. 


\section{Higher Education in Nigeria}

Nigeria as a country is naturally endowed with large population, the vast population require skilled manpower to run the economic need of the country's people, and these skills needed can only be trained by the higher education system of the country, especially the university system (Dauda, 2010; Knowles, Swanson, \& Holton III, 2011; Pathik et al., 2012). Therefore, the university systems and higher education systems responsible for providing the manpower need of the country have to have sufficient HR at its disposal in order to be able to meet the HR requirement of the nation in general. This is calls for proper administration and management of university systems and higher education system in realization of the importance of the administration and management in higher education system in Nigeria (Modebelu \& Joseph, 2012).

Higher education in Nigeria implies the kind of education offered subsequent to secondary education in dedicated institutions such as universities, colleges of education, polytechnics, monotechnics and other allied and specialized institutions (Halstead, 1974; Modebelu \& Joseph, 2012). According to Modebelu and Joseph (2012), they further described higher education in terms of the goals it seek to attain and the function of it in national development. They stated categorically that: "higher education contribute to manpower training, local capacity development, intellectual development, advancement of scholarship and community development and promotion of interaction between national and international understanding" (Halstead, 1974; Modebelu \& Joseph, 2012). From the forgoing, higher education is the kind of education responsible for professional and skilled development of the population for the purpose of growth and development. Higher education in Nigeria and like any other country is mainly intended for the development of technocrat and the high-manpower that will be responsible for the operations of the wheels and machines of the economy. The wheels of economy of a country refers the production, agriculture, manufacturing, health and service sectors, these are sectors responsible for the continuous advancement of the country and these sectors are people driven. They are sectors that work in rotations with one another to make a possible country hood. The various sectors are operated and driven by people (Castells, 2010). These people are the human resource of country and they are to be trained and developed by the higher education system of the country; and in the long run a significant percentage of these people trained will have to return back to higher education system as human resource inputs for the system (Clancy \& Goastellec, 2007; Folger et al., 1970; Pathik et al., 2012). On this note, the importance of higher education in a country such as a Nigeria cannot be overemphasized in the light of its vital importance in Human Resource Development (Adamolekun, 1983; Dauda, 2010; Ekundayo \& Ajayi, 2009; Oyewole, 2009).

\section{Administration: Roadmap to Total Quality Management in Universities in Nigeria}

The general body responsible for universities and degree awarding institutions in Nigeria is National Universities Commission (NUC). NUC is a regulatory body and standard setting body for the universities and degree awarding institutions in Nigeria (Okebukola, 2002). Statutorily NUC is formed as a body enabled by the government laws to develop framework and benchmark of quality in process and service; that is in terms of the performance of human resource input in Nigerian universities and degree awarding institutions (Saint, Hartnett, \& Strassner, 2003). The role of NUC in Human Resource Development and Situation in Nigerian universities cannot be over emphasized; as NUC attempts to move university education in Nigeria to international standard on continuous basis, through several strategy such as; standard and benchmark setting, regulatory frameworks and accreditations. In this light NUC can be liken to a quality standard body in Total Quality Management Parlance (Akerele, 2012.; Okechukwu \& Okechukwu, 2011). This kind of body is necessary for the purpose continuous quality improvement in operations and services such, International Standard Organization (ISO).

In the world of learning today, Universities are mandated by the dynamism of change towards providing cutting edge knowledge in Research and Development (R\&D) so that graduates can compete globally. On this note, a body such as NUC in Nigerian university is needed to focus more on pushing for quality assurance in Human Capital Development at both input level and output level of Nigerian universities (Saint et al., 2003).

However, NUC have over the years established a formidable landmark in the university systems in Nigeria, in terms of human capital development through its regulatory framework on the promotions of lecturers in Nigerian universities (Adekola, 2012). In recent years, the push of NUC regulatory frameworks on the promotion of teaching staffs in the university, have seen a good number of increase in the number of staff holding $\mathrm{PhD}$ academic qualifications. The NUC regulatory framework on promotion of university academic staff, serves as a push factor, a positive motivation, for the continuous quality improvement, professional and career development of universities lecturers in Nigeria. The implication and summary of these continuous quality improvements, professional and career development, is Human Resource Development of the university academic staff members; and ultimately the effect of human resource development of the academic staff members will transfer 
to the 'turn outs' from the university systems, the graduates who are going to be manpower thresholds of the national economy (Adedokun-Shittu, Sheikh Ahmad, Othman, Ahmad, \& Badariah, 2012; Agarwal, 2009; Kaul, 2010; Pathik et al., 2012; Samoff \& Carrol, 2003).

In a similar tune, in a study of 22 universities spanning access 8 different countries, Gibbs and Coffey (2004) established documented proofs that continuous training and development of academic teachers in citadel of learning like universities have positive influence on the performance and academic ability and achievement of the students. Universities and citadel of higher education learning are places for professional development for the both teachers and the students; this falls on the main fact that students of universities of today are going to turn out to become thresholds for the economy in the future (Gibbs \& Coffey, 2004; Yusuf, Ajidagba, Agbonna, \& Olumorin, 2010). From the forgoing, the quality of university graduates has been established to be dependent on the quality of human resource input in the university. That is high quality and high developed university teachers are able to impact effective knowledge for the development of the students who are going, later, to be the custodians of the national economy.

Based on this, with the support of other empirical evidences such as that of Gibbs and Coffey (2004) and Pathik et al., (2012), the relationship between the Human Resource Development of university academia and HRD development at organization level, community level and national level is 'transactional'. That is the effect of HRD development of universities on the society is 'give and take' (Garavan \& McGuire, 2010; Knowles et al., 2011; Weisbrod, 1962). Considering it from Corporate Social Responsibility (CSR) which is one of the fundamentals of HRD (Garavan \& McGuire, 2010), university systems as the pot base of knowledge should be morally and ethically responsible and committed to society for sustainable development in terms of human capacity and human capital development; in view of the fact that a good numbers of knowledge recipients and development recipients at the university system will return back into the system as inputs of human resource. In this line, there is a transaction between the society and university system, when university system applied proper human resource policies in its operation; 'it is going to get paid in its own coin when outputs of the systems return back into it from the society as inputs of human resource' (Mok, 2012).

Apart from the fact that some of the output of university system will have to return into the systems as HR inputs; the other ones that may not return back into the system will have to take to certain economic activities or service in nation on which the university system depend on its operations. Up to this point, the transaction still continues and weigh highly important between the society and the university as a result of the fact the two are strongly inter-dependent in the area of Human Resource Development and Human Resource Mobility and Supply (Filatotchev, Liu, Lu, \& Wright, 2011). Based on this, the human resource management and administration of universities in Nigeria both at individual university level and national level, such as National University Commission (NUC) hold important bearing on the overall HR situation of Nigeria and ultimately on the economic growth and development of the county. That is the better, the HR inputs in the universities, in terms human capital development of universities teachers measured by $\mathrm{PhD}$ completion, contribution to Research and Development (R\&D) both locally and internationally; the better the HR situation of the society as well as the economic yield of the country. This is based on the theories of National Human Capital Development (NHCD), made popular by erudite scholars such as Becker (Gary S. Becker, 2011) and McLean (Gary N. McLean, Kuo, Budhwani, Yamnill, \& Virakul, 2012). On this, scholars and researchers (Gary S. Becker, 2011) posit that Education and Technology coupled with Health are tools for human capital development at individual level, organizational level and national level. Advancement in Human Capital Development (HCD) implies high skills capacity for the nation at the aggregate; meaning that there is large percentage of the people who perform beyond their native ability due to expansion in skills and capacity building which leads to development (G. N. McLean, 2004; Swanson, 1995). On this note, HR at the university system should not be taken lightly in view of the fact of the implication of it at the national level towards economic growth and development.

\section{Conclusion}

Today's world of dynamic changes, more than ever before in human history and notably since after the Second World, wealth or poverty of nations depends on the quality of higher education. As a result of the fact that, economic development and infrastructural development depends squarely on the skills, ability and drives available in human components of the country to power the wheels of services and production of the country (Alam, Hoque, Rout, \& Priyadarshani, 2010; Moore \& Anderson, 2012).

Before now, it was previously conceptually believed that development of nations is based majorly on economic figures such as GDP (Gross Domestic Product) and other economic indices, while paying little attention to the human development indicators such as Human Development Index (HDI) which is based primarily on health and 
education level of the people. The wrong of measuring development based on economic indices, is further proved by the fact of countries of the world that are not endowed with natural resources but endowed with wealth of skilled populations and they are referred to as highly developed country, example of a country like this is Japan (Gerring, Thacker, \& Alfaro, 2012; McMichael, 2011; Ray, 2011). While, on the other hand, there are countries with vast natural endowment such crude oil and others and they do not come near the standards of being termed as developed nations. There are even countries with world accredited infrastructures in terms of wonder buildings and yet they are not known as developed countries.

On this note, it is clear that development of a country is based on the general quality of life and quality labor or quality of work life of the country, while quality of work life of the population is a function of Human Resource Development of the total population (McMichael, 2011). The shift in the paradigm of economic- based measurement of development to human- development based- measurement is informed by the reasoning that economic progression of any country is dependent on the quality of skills and health of the population. The population must first be skillful and healthful enough to move the economic wheel forward, before economic growth can be recorded (Aluko \& Aluko, 2012; G. S. Becker, 1994; Cohen \& Soto, 2007; McDonald \& Roberts, 2002). Therefore, in positioning the skillful disposition of the populace towards development, proper quality approaches in HRD must be applied.

In this light, countries such as Nigeria should deploy quality strategies, in Total Quality Management (TQM) and Continuous Quality Improvement (CQI) to expand and improve the capacity of the manpower of the entire populace through established systems like university system and quality higher education. Quality strategies improve and expand performance beyond the natural possible limits across innovation and Human Resource Development (Abdullah, 2010; Sutherasan \& Aungsuroch, 2010; Talib, Rahman, \& Qureshi, 2011; Weisbrod, 1962).

In view of the vital need of quality in the life performance of people of Nigeria so that the country can belong among the comity of developed countries, higher education systems which has always been the arrowhead of development in developed countries of the world should be laced and administered with TQM and CQI for the purpose of rapid overall Human Resource Development. Towards this end, the university systems administration both at central (NUC) and institutional level should make use of latest technology to expand learning capacity among the scholars(lecturers) and students towards innovation and Human Resource Development (Alam, 2009).

\section{References}

Abdullah, A. (2010). Measuring TQM implementation: A case study of Malaysian SMEs. Measuring Business Excellence, 14(3), 3-15.

Adamolekun, L. (1983). Public administration: A Nigerian and comparative perspective. Addison-Wesley Longman Ltd.

Adedokun-Shittu, N. A., Sheikh Ahmad, I., Othman, J., Ahmad, T., \& Badariah, T. (2012). The Deployment of ICT facilities in teaching and learning in higher education: a mixed method study of its impact on lecturers and students. Retrieved from http://irep.iium.edu.my/24250/

Adekola, B. (2012). The Role of Status in Job Satisfaction Level of Academic staff in Nigerian Universities. International Journal of Management \& Business Affairs, 2(1), 1-10.

Agarwal, P. (2009). Higher education in India: The need for change. Retrieved from http://dspace.cigilibrary.org/jspui/handle/123456789/20971

Akerele, W. O. (n.d.). Quality Assurance in Nigeria's University System: The Imperatives for the 21 st Century. Retrieved http://www.herp-net.org/TOWARDS_QUALITY_IN_AFRICAN_HIGHER_EDUCATION/Chapter\%207. pdf

Alam, G. M. (2009). The role of science and technology education at network age population for sustainable development of Bangladesh through human resource advancement. Sci. Res. Essays, 4(11), 1260-1270.

Alam, G. M., Hoque, K. E., Khalifa, M. T. B., Siraj, S. B., \& Ghani, M. (2009). The role of agriculture education and training on agriculture economics and national development of Bangladesh. Afr. J. Agric. Res, 4(12), $1334-1350$. 
Alam, G. M., Hoque, K. E., Rout, G. K., \& Priyadarshani, N. (2010). Who gains from EFA-State Business of Education or Private Higher Education Business in Developing Nation: A study to understand the policy impact in Bangladesh? Afr. J. Bus. Manage, 4(5), 770-789.

Aluko, Y. A., \& Aluko, O. (2012). Human Capital Development: Nigeria's Greatest Challenge. Journal of Management, 13(1), 163.

Becker, G. S. (1994). Human capital: A theoretical and empirical analysis, with special reference to education. University of Chicago Press. Retrieved from http://books.google.com.my/books?hl=en\&lr=\&id=9t69iICmrZ0C\&oi=fnd\&pg=PR9\&dq=Gary+Becker\&o ts $=$ WvAmpWNshT\&sig=0OBVVOySbDcZK9ajszDSGuAluto

Becker, Gary S. (2011). The Oxford handbook of human capital. OUP Oxford. Retrieved from http://books.google.com.my/books?hl=en\&lr=\&id=84DgXQ8mq50C\&oi=fnd\&pg=PP2\&dq=Becker:+Nati onal+Human+Capital+Development\&ots=nt3hxzSoGW\&sig=SqO5Mx4DMBhF7bLB2dIoycCOGKw

Bhagavatula, S., Elfring, T., Van Tilburg, A., \& Van De Bunt, G. G. (2010). How social and human capital influence opportunity recognition and resource mobilization in India's handloom industry. Journal of Business Venturing, 25(3), 245-260.

Biggs, J., \& Tang, C. (2011). Teaching for quality learning at university. Open university press. Retrieved from $\mathrm{http} / /$ books.google.com.my/books?hl=en\&lr=\&id=XhjRBrDAESkC\&oi=fnd\&pg=PP1\&dq=Managing $+\mathrm{Ch}$ ange + and + quality + in + the + university + system $\&$ ots $=$ m3waOUohGP\&sig $=$ uaWKHXEhrtOoRq9Hv7R1D-hw $\mathrm{jJE}$

Black, J. W. (2010). Product-level Bill of Material Development Methodology: process implementation. Massachusetts Institute of Technology. Retrieved from http://dspace.mit.edu/handle/1721.1/59153

Castells, M. (2010). End of Millennium: The Information Age: Economy, Society, and Culture (Vol. 3). Wiley-Blackwell. Retrieved from http://books.google.com.my/books?hl=en\&lr=\&id=1wDLJAGDRGYC\&oi=fnd\&pg=PA14\&dq=Arms + of + the+economy + of + a ++ nation\&ots $=$ gn $3 z 6 G e 2 y d \& s i g=U Z n F H e 1 z d Z N F 39 h c w K P F O V C Y k T s$

Cho, E., \& McLean, G. N. (2004). What we discovered about NHRD and what it means for HRD. Advances in Developing Human Resources, 6(3), 382-393.

Clancy, P., \& Goastellec, G. (2007). Exploring access and equity in higher education: Policy and performance in a comparative perspective. Higher Education Quarterly, 61(2), 136-154.

Cohen, D., \& Soto, M. (2007). Growth and human capital: Good data, good results. Journal of economic growth, 12(1), 51-76.

Cozzens, S. E. (2012). Social cohesion at the global level: The roles of science and technology. Science and Public Policy. Retrieved from http://spp.oxfordjournals.org/content/early/2012/08/30/scipol.scs067.abstract

Dauda, R. O. S. (2010). Investment in Education and Economic Growth in Nigeria: An Empirical Evidence. International Research Journal of Finance and Economics, 55, 158-169.

Ekundayo, H. T., \& Ajayi, I. A. (2009). Towards effective management of university education in Nigeria. International NGO journal, 4(8), 342-347.

Ellison, N. B., Steinfield, C., \& Lampe, C. (2011). Connection strategies: Social capital implications of Facebook-enabled communication practices. New Media \& Society, 13(6), 873-892.

Evans, L., Thornton, B., \& Usinger, J. (2012). Theoretical Frameworks to Guide School Improvement. NASSP Bulletin, 96(2), 154-171.

Filatotchev, I., Liu, X., Lu, J., \& Wright, M. (2011). Knowledge spillovers through human mobility across national borders: Evidence from Zhongguancun Science Park in China. Research Policy, 40(3), 453-462.

Folger, J. K., Astin, H. S., \& Bayer, A. E. (1970). Human resources and higher education. Russell Sage Foundation.

Frederickson, H. G., Smith, K., \& Larimer, C. (2011). The public administration theory primer. Westview Press.

Fulton-Calkins, P., \& Stulz, K. M. (2008). Procedures \& Theory for Administrative Professionals. South-Western Pub. Retrieved from http://books.google.com.my/books?hl=en\&lr=\&id=x07m1SQP-qEC\&oi=fnd\&pg=PR7\&dq=Procedures + an 
$\mathrm{d}+$ Theory+for+Administrative+Professionals\&ots=4EYxmag0f0\&sig=fP9SMtYSMtvAfWOOTM_MzC3Y Xs4

Garaj, V. (2010). M-Learning in the education of multimedia technologists and designers at the university level: A user requirements study. Learning Technologies, IEEE Transactions on, 3(1), 24-32.

Garavan, T. N., \& McGuire, D. (2010). Human resource development and society: Human resource development's role in embedding corporate social responsibility, sustainability, and ethics in organizations. Advances in Developing Human Resources, 12(5), 487-507.

Gerring, J., Thacker, S. C., \& Alfaro, R. (2012). Democracy and human development. The Journal of Politics, $74(01), 1-17$.

Gibbs, G., \& Coffey, M. (2004). The impact of training of university teachers on their teaching skills, their approach to teaching and the approach to learning of their students. Active learning in higher education, $5(1), 87-100$.

Gupta, P. K. (2010). Impact of universities on the development of nations: An analysis from social perspective. Retrieved from http://dspace.nehu.ac.in/handle/1/3775

Hallam, C. R., Muesel, J., \& Flannery, W. (2010). Analysis of the Toyota Production System and the genesis of Six Sigma programs: An imperative for understanding failures in technology management culture transformation in traditional manufacturing companies. In Technology Management for Global Economic Growth (PICMET), 2010 Proceedings of PICMET'10 (pp. 1-11). Retrieved from http://ieeexplore.ieee.org/xpls/abs_all.jsp?arnumber $=5602106$

Halstead, D. K. (1974). Statewide Planning in Higher Education. Retrieved from http://www.eric.ed.gov/ERICWebPortal/recordDetail?accno=ED096914

Hansmann, H. (1987). Economic theories of nonprofit organization. The nonprofit sector: A research handbook, 1. Retrieved from http://www.ppge.ufrgs.br/giacomo/arquivos/eco02072/hansmann-1987.pdf

Ito, M. (2005). Mobile phones, Japanese youth, and the re-placement of social contact. Mobile Communications, 131-148.

Kaul, J. N. (2010). Higher education, social change and national development. Retrieved from http://14.139.58.196:8080/xmlui/handle/123456789/169

Keller, K. L., Parameswaran, M. G., \& Jacob, I. (2011). Strategic brand management. Pearson Education India.

Knowles, M. S., Swanson, R. A., \& Holton III, E. F. (2011). The adult learner: The definitive classic in adult education and human resource development. Butterworth-Heinemann. Retrieved from $\mathrm{http} / /$ books.google.com.my/books?hl=en\&lr=\&id=Y3bQEL_3OEIC\&oi=fnd\&pg=PR1\&dq=The+relations hip+between+human+resource+and+higher+education\&ots=Vh8Cx1zfEC\&sig=IAvWDjA0gmFGnvLN8J dp891J2t8

Kreutzer, T. (2009a). Generation mobile: Online and digital media usage on mobile phones among low-income urban youth in South Africa. U. of Cape Town, SA. Retrieved from http://tinokreutzer.org/mobile/MobileOnlineMedia-SurveyResults-2009.pdf

Kreutzer, T. (2009b). Generation mobile: Online and digital media usage on mobile phones among low-income urban youth in South Africa. U. of Cape Town, SA. Retrieved from http://tinokreutzer.org/mobile/MobileOnlineMedia-SurveyResults-2009.pdf

Kumar, M. (2011). Impact of the Evolution of Smart Phones in Education Technology and its Application in Technical and Professional Studies: Indian Perspective. arXiv preprint arXiv:1109.0937. Retrieved from http://arxiv.org/abs/1109.0937

Lange, D. (1988). Tomorrow's schools: The reform of education administration in New Zealand.

Laplante, A. (2011). Social Capital and Music Discovery: An Examination of the Ties Through Which Late Adolescents Discover New Music. Retrieved http://www.mirlab.org/conference_papers/International_Conference/ISMIR\%202011/papers/OS5-2.pdf

Lorenzi, N. M., \& Riley, R. T. (2000). Managing Change An Overview. Journal of the American Medical Informatics Association, 7(2), 116-124.

McDonald, S., \& Roberts, J. (2002). Growth and multiple forms of human capital in an augmented Solow model: A panel data investigation. Economics Letters, 74(2), 271-276. 
McLean, G. N. (2004). National human resource development: What in the world is it? Advances in Developing Human Resources, 6(3), 269-275.

McLean, G. N. (2006). National human resource development: A focused study in transitioning societies in the developing world. Advances in Developing Human Resources, 8(1), 3-11.

McLean, Gary, N., Kuo, M.-H. C., Budhwani, N. N., Yamnill, S., \& Virakul, B. (2012). Capacity Building for Societal Development Case Studies in Human Resource Development. Advances in Developing Human Resources, 14(3), 251-263.

McMichael, P. (2011). Development and social change: A global perspective. Sage Publications, Incorporated.

Modebelu, M. N., \& Joseph, A. (2012a). Strategic Planning Procedure: An Imperative for Effective Management of Higher Education in Nigeria. Mediterranean Journal of Social Sciences. Retrieved from http://www.mcser.org/images/stories/MJSS-Special-issues/MJSS\%202012\%20Special\%20Issue\%20vol\%2 03\%20no\%2015/Modebelu,\%20M.pdf

Modebelu, M. N., \& Joseph, A. (2012b). Strategic Planning Procedure: An Imperative for Effective Management of Higher Education in Nigeria. Mediterranean Journal of Social Sciences. Retrieved from http://www.mcser.org/images/stories/MJSS-Special-issues/MJSS\%202012\%20Special\%20Issue\%20vol\%2 03\%20no\%2015/Modebelu,\%20M.pdf

Mok, K. H. (2012). The quest for innovation and entrepreneurship: The changing role of university in East Asia. Globalisation. Societies and Education, 10(3), 317-335.

Moore, M. G., \& Anderson, W. G. (2012). Handbook of distance education. Routledge.

Morrison, K. (2010). Complexity theory, school leadership and management: questions for theory and practice. Educational Management Administration \& Leadership, 38(3), 374-393.

Nakpodia, E. (2011). Team Management as an Effective Technique for the Management of Schools in Nigeria. African Journal of Social Sciences, 1(1), 83-91.

Okebukola, P. (2002). The state of university education in Nigeria. Abuja: National Universities Commission.

Okechukwu, F. C., \& Okechukwu, F. C. (2011). Total Quality Management in Higher Education: Symbolism Or Substance? a Close Look at the Nigerian University System. AuthorHouse. Retrieved from $\mathrm{http} / /$ books.google.com.my/books?hl=en\&lr=\&id=IA-t48SPgzwC\&oi=fnd\&pg=PR11\&dq=TQM+in+Nige rian+Universities\&ots $=$ PlXW1z5kWb\&sig $=$ Wyo1xQ3HTMK_7-1-3Eb053c_TxQ

Onovughakpo, F. C. (2012). Greater Access to Higher Education Through Communication Technologies in Sub-Saharan Africa: E-Learning Readiness of Distance Education Students in Nigeria. Athabasca University. Retrieved from https://dt.athabascau.ca/jspui/handle/10791/19

Oyewole, O. (2009). Internationalization and its implications for the quality of higher education in Africa. Higher Education Policy, 22(3), 319-329.

Pathik, B. B., Chowdhury, M. T., \& Habib, M. M. (2012). A descriptive study on supply chain management model for the academia. In Management of Innovation and Technology (ICMIT), 2012 IEEE International $\begin{array}{lllll}\text { Conference } & \text { On } & \text { (pp. 191-196). } & \text { Retrieved }\end{array}$ http://ieeexplore.ieee.org/xpls/abs_all.jsp?arnumber=6225803

Peters, A. A. (2009). Population and Human Resource Development in Nigeria. lecture delivered at the National Defence College. Abuja Nigeria to Participants of Course, 18(7). Retrieved from http://www.ndc.gov.ng/Lectures/Population-and-HRD.pdf

Potnis, D. D. (2010). Mobile Technologies \& Socio-Economic Opportunities for Disadvantaged Women: A Study of Information Behavior in a Developing Nation Context. ERIC. Retrieved from http://www.eric.ed.gov/ERICWebPortal/recordDetail?accno=ED520178

Quinn, A., Lemay, G., Larsen, P., \& Johnson, D. M. (2009). Service quality in higher education. Total Quality Management, 20(2), 139-152.

Ray, D. (2011). Development economics. Princeton University Press. Retrieved from http://books.google.com.my/books?hl=en\&lr=\&id=GKr5RxWT4uAC\&oi=fnd\&pg=PP2\&dq=Measurement + of + countries $\% 27+$ rate + of + development + based + on + human + development\&ots $=r 4 \mathrm{mFHnVrit} \&$ sig $=\mathrm{VIr} 65 \mathrm{~V}$ PzF9dN9TknqzYsIuRkBTs 
Richard, I. L. (2011). Quantitative approaches to management. Retrieved from http://www.digitallibrary.kcci.com.pk/handle/32417747/697

Saint, W., Hartnett, T. A., \& Strassner, E. (2003). Higher education in Nigeria: A status report. Higher Education Policy, 16(3), 259-281.

Samoff, J., \& Carrol, B. (2003). From manpower planning to the knowledge era: World Bank policies on higher education in Africa. Retrieved from http://afaq.kfupm.edu.sa/features/Carrol.pdf

Schwantz, G. D. (2012). Service quality in higher education: Expectations and perceptions of traditional and non-traditional students. Retrieved from http://repositories.tdl.org/tdl-ir/handle/2346/12914

Shortell, S. M., O’Brien, J. L., Carman, J. M., Foster, R. W., Hughes, E. F., Boerstler, H., \& O'Connor, E. J. (1995). Assessing the impact of continuous quality improvement/total quality management: Concept versus implementation. Health services research, 30(2), 377.

Smart, J. C., \& Paulsen, M. B. (2011). Higher education: Handbook of theory and research (Vol. 26). Springer. Retrieved from http://books.google.com.my/books?hl=en\&lr=\&id=3OZ6ymPgjGgC\&oi=fnd\&pg=PR5\&dq=University + as +education++business+center\&ots $=$ m0fZp8XsMH\&sig=GEZ88AoGBL6QowL68Hm_rSS3dy8

Sousa, R., \& Voss, C. (2012). The impacts of e-service quality on customer behaviour in multi-channel e-services. Total Quality Management \& Business Excellence, 23(7-8), 789-806.

Suri, T., Boozer, M. A., Ranis, G., \& Stewart, F. (2011). Paths to success: The relationship between human development and economic growth. World Development, 39(4), 506-522.

Sutherasan, S., \& Aungsuroch, Y. (2010). Total quality management activities after hospital accreditation from the opinion of hospital accreditation coordinators in Thailand. Songklanagarind Medical Journal, 26(4), 313-321.

Swanson, R. A. (1995). Human resource development: Performance is the key. Human Resource Development Quarterly, 6(2), 207-213.

Talib, F., Rahman, Z., \& Qureshi, M. N. (2011). Analysis of interaction among the barriers to total quality management implementation using interpretive structural modeling approach. Benchmarking: An International Journal, 18(4), 563-587.

Valenzuela, S., Park, N., \& Kee, K. F. (2009). Is There Social Capital in a Social Network Site?: Facebook Use and College Students' Life Satisfaction, Trust, and Participation1. Journal of Computer-Mediated Communication, 14(4), 875-901.

Weisbrod, B. A. (1962). Education and investment in human capital. The Journal of Political Economy, $106-123$.

Wheelen, T. L., \& Hunger, J. D. (2011). Concepts in strategic management and business policy. Pearson Education India.

Woolcock, M., \& Narayan, D. (2000). Social capital: Implications for development theory, research, and policy. The world bank research observer, 15(2), 225-249.

Wynne, B. G. (2010). Managing knowledge in small non-profit organizations: A toolkit and research report. The Atlantic Canada Social Economy Regional Node, Project No. S. Retrieved from http://dc.msvu.ca:8080/fr/handle/10587/1065 